\title{
Indian marsh mugger and its tunnel residency behavioural patterns in a sanctuary premises in Haryana, India
}

\author{
Rohtash Chand Gupta \\ Department of Zoology, Kurukshetra University, Kurukshetra (Haryana), INDIA \\ Present Address: H.No-566/3, Urban Estate, Kurukshetra (Haryana), INDIA \\ E-mail: rohtashchandgupta@ rediffmail.com
}

Abstract: The present studies endeavour to focus attention on the Tunnel behavior of Indian Marsh Mugger in "Bhor Sainda Crocodile Sanctuary" in Kurukshetra district of Haryana state in India. The Sanctuary premises are spread over an area of about 25-30 Acres with a good marshy land and a central earth mound which is having 12-15 tunnels. Observations reveal that Indian Marsh Mugger is accustomed to spend time in Tunnels during the night without any exception in normal conditions. However, if the tunnels are damaged due to one or the other reason, then Muggers may compulsively stray in the open during night time. All the tunnels are seldom in use at any given time.Tunnels are necessarily used for eggs laying by the females. Tunnels are in very bad shape in this Sanctuary.Tunnels are scattered on the earth mound all across with no specific pattern or style. However, most of the tunnels are located in the centre of the earth mound. Tunnels were in very good position during 1985-1990. However, now these tunnels are in very bad shape. Most of these are now stuffed with debris and appear defunct. These have directly affected the hatching of eggs which are necessarily laid in tunnels by muggers at this Sanctuary site.

Keywords: Indian marsh mugger, Tunnels, Bhor Sainda crocodile sanctuary, Kurukshetra, Haryana

\section{INTRODUCTION}

Most muggers are available in holy tanks in southern India and Srilanka along with rivers like Chambal, Yamuna, Ganga and Mahanadi in Orissa. Yet, Muggers are in abundance in various Zoos and Mamllapuram Crocodile Park in TamilNadu. However, "Bhor Sainda Crocodile Sanctuary" in Kurukshetra district in Haryana is a unique system providing ideal conditions for studying behavior of Muggers. In the present studies, observations are spread over 25 years. The information on Muggers in this sanctuary has been given by (Gupta and Bhardwaj, 1992, 1993a-c). Others who have focused attention on tunnel residency are Gupta and Hari (1989, 1990). Elsewhere in India, workers like Singh and Bustard (1977); Bustard and Singh (1975); Whitaker and Basu (1983); Rao and Singh, (1994); Maskey and Bellairs (1977); carried out research work in India and abroad on the tunnel behaviour of Marsh Muggers. Joseph et al. (1975) have reported about the natural history of Marsh Mugger but excluding its tunnel behavior. Kay (2004a-b) and Read et al. (2007) and have also studied crocodiles to understand their natural history. The aim of the present study was to focus attention on the Tunnel behavior of Indian Marsh Mugger in "Bhor Sainda Crocodile Sanctuary" in Kurukshetra (Haryana) state in India.

\section{MATERIALS AND METHODS}

Study site: It is amazing to note that there is a "Crocodile
Sanctuary" in Kurukshetra district in Haryana. The Crocodile sanctuary came into existence in 1982 when a "Temple Tank" having 25-30 muggers was upgraded as "Sanctuary" by Govt. of Haryana. Actually this sanctuary is located beside a village, namely "Bhor-Sainda Crocodile Sanctuary "in Kurukshetra district and hence its name "Bhor Sainda Crocodile Sanctuary."

In contrast to vast area, required to generate account on natural history of Marsh Mugger in India focusing attention on the vast basins of rivers like Yamuna, Ganga, Chambal, and Mahanadi, the present Crocodile Sanctuary site is an ideal site, bypassing frustration of tracking and boating and yielding no substantially clues.

The present study site is, namely, "Bhor Sainda Crocodile Sanctuary." Bhor Sainda village is a part of "Pehowa Sub -Divisional Block" of Kurukshetra which is $157 \mathrm{Kms}$ away from Delhi on NH-1 in the North.

This Sanctuary has a glorious past directly related with conservation of biodiversity through religious ethics, rituals, preachings and bindings. According to the Sadhus now in charge of the Temple, their Guru brought Muggers around 250-300 years ago to the tank and inspired the villagers to have affiliation with the Muggers by way of "Food-Offerings" and "Worship". The study is an ideal habitat in a limited dimensions providing virtually the best location for understanding the basics of behavioral patterns of Marsh Mugger. In the present paper, it has been endeavored to put in place, facts in 
Table 1. Showing the time spent by the Indian marsh mugger in general in tunnel at Bhor Sainda crocodile sanctuary in Kurukshetra in the last 25 years (1985-2010).

\begin{tabular}{llccc}
\hline S.No. & M onth & & \multicolumn{2}{c}{ I Ime spent in tunnel } \\
\cline { 3 - 5 } & & Entry time & Exit time & Time spent in tunnels \\
\hline 1 & January & $4: 30 \mathrm{PM}$ & $7: 00 \mathrm{PM}$ & $14: 30 \mathrm{Hrs}$ \\
2 & February & $5: 30 \mathrm{PM}$ & $7: 00 \mathrm{AM}$ & $13: 30 \mathrm{Hrs}$ \\
3 & March & $7: 00 \mathrm{PM}$ & $6: 00 \mathrm{AM}$ & $11: 00 \mathrm{Hrs}$ \\
4 & April & $7: 00 \mathrm{PM}$ & $5: 00 \mathrm{AM}$ & $10: 00 \mathrm{Hrs}$ \\
5 & May & $7: 00 \mathrm{PM}$ & $5: 30 \mathrm{AM}$ & $10: 30 \mathrm{Hrs}$ \\
6 & June & $7: 45 \mathrm{PM}$ & $4: 00 \mathrm{AM}$ & $8: 15 \mathrm{Hrs}$ \\
7 & July & $7: 30 \mathrm{PM}$ & $4: 30 \mathrm{AM}$ & $9: 00 \mathrm{Hrs}$ \\
8 & August & $7: 00 \mathrm{PM}$ & $5: 30 \mathrm{AM}$ & $10: 30 \mathrm{Hrs}$ \\
9 & September & $6: 30 \mathrm{PM}$ & $6: 00 \mathrm{AM}$ & $11: 30 \mathrm{Hrs}$ \\
10 & October & $5: 00 \mathrm{PM}$ & $6: 00 \mathrm{AM}$ & $13: 00 \mathrm{Hrs}$ \\
11 & November & $5: 00 \mathrm{PM}$ & $7: 00 \mathrm{AM}$ & $14: 00 \mathrm{Hrs}$ \\
\hline
\end{tabular}

respect of "Tunnels-Behaviour." The main physical attribute of the Sanctuary include a vast sheet of marshy wetland and an earth mound. This mound is the site of "Tunnels."

This sanctuary is under observations, way back from 1985. Atleast, 2-3 visits were made in every year and each visit lasted for a day covering day and night. Specific attention was paid at dusk and dawn to record proper entry and departure time in the evenings and mornings. Supplementary visits were made in apex time of every season to know the influence of severe winter and scorching summers.

\section{RESULTS AND DISCUSSION}

Reptiles undergo hibernation in winter season. Crocodiles, despite being reptiles bypass hibernation. This is possible, among other factors, due to basking in sun and staying in deep tunnels above ground, very potential and effective means of getting warmth to raise the body temperature. In the present paper tunnel behavior has been investigated into. Tunnel behavior has been looked into by earlier workers like Singh and Bustard (1977); Whitaker and Basu (1983); Rao and Singh (1994) and Maskey and Bellairs (1977) who have opined that muggers keep the options open whether to remain on open ground or tunnels in the night time. However, the present studies certainly hint towards the fact that if the tunnels are in place, crocodiles retire through the night, necessarily in tunnels only at "Bhor Sainda Crocodile Sanctuary."

In so far as the physical structural parameters of tunnels is concerned, it is interesting to note that these have one "Outlet" which serve as "Exit" and Entrance and is thus not a tunnel but a burrow. However all scientists have popularly used "tunnel" word. Heretoo, the word tunnel has been adapted. These tunnels have an oblong shape (Figs. 1-6) at the mouth point with a slightly curved straight path leading into spacious chamber where one/ two or three crocodiles retire during the night. These tunnels were never attempted to be discovered from inside for fear of destruction of the tunnels. The females were generally seen stationed just at the entrance of tunnels in late June and July every year, obviously guarding the eggs. It is interesting to note that at Bhor Sainda Crocodile Sanctuary, eggs are always laid inside the tunnels. In contrast; some authors have reported that Marsh Mugger lays eggs on ground in a heap of plant litter and soil. The broken shells of eggs were collected even in September 2010 at the sanctuary site (Table 1, Figs. 1-6).

In so far as the distribution of tunnels is concerned on the body of earth mound at the study site, present studies reveal that there is no distinct pattern. Yet, mugger shows tendency to occupy tunnels at the highest positions on the earth mound (Figs. 1-6). In contrast, very young Crocodiles were always seem to prefer tunnels which were dug in the vertical façade of earth at the lower rim of the mound at the level of water sheet. Perhaps this is to avoid the frequent attacks by the adult male muggers. Another interesting feature relates to the fact that "few tunnels" always remain out of use at a given time. Yet, such tunnels which are in use, show fresh signatures of occupancy by way of dagging-pathways of Crocodiles. The present studies indicate clearly that all tunnels are never in use at any point of time in a year.

In case of Indian Saltwater Crocodile, Gopi et al. (2007) 

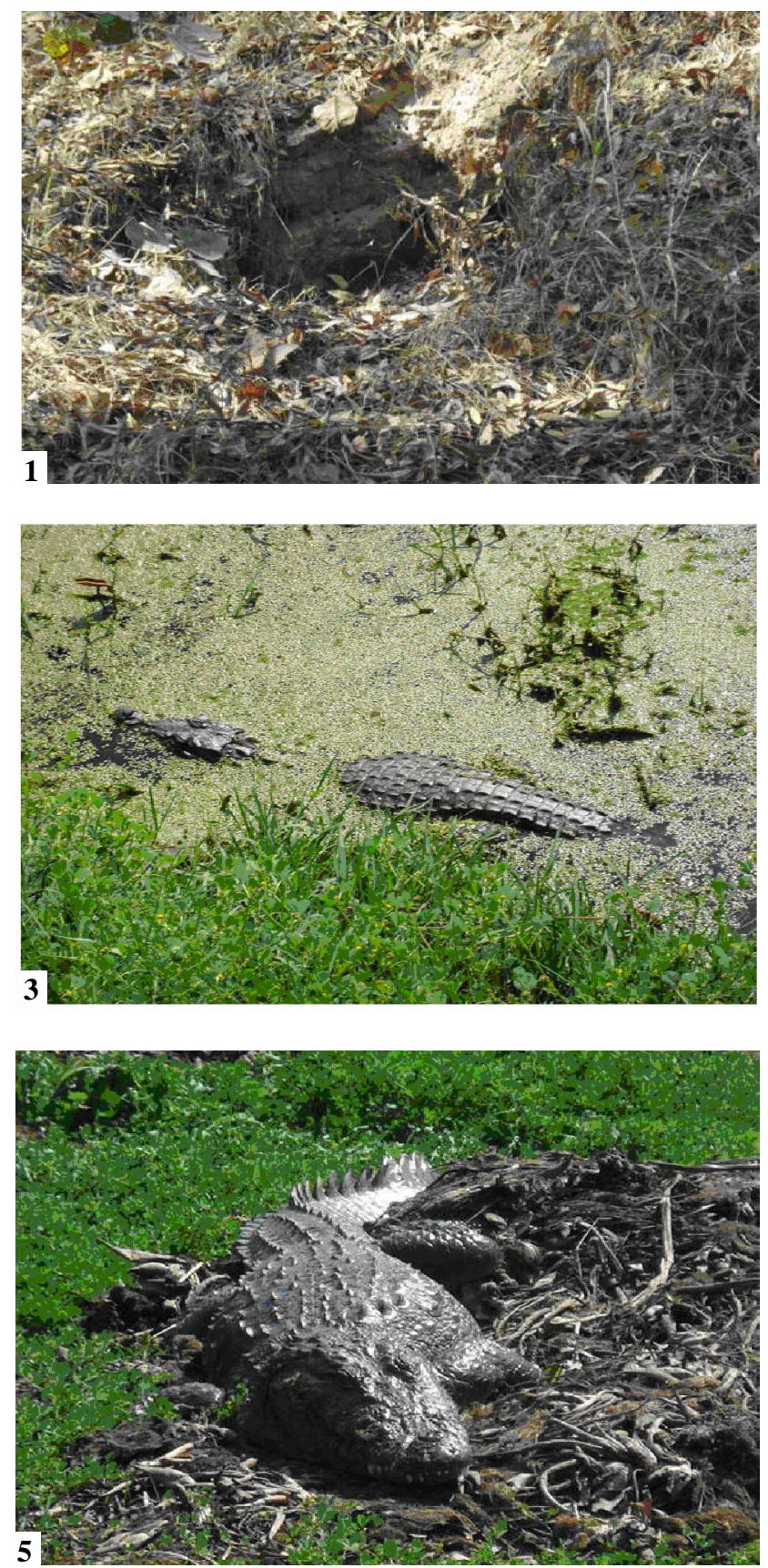
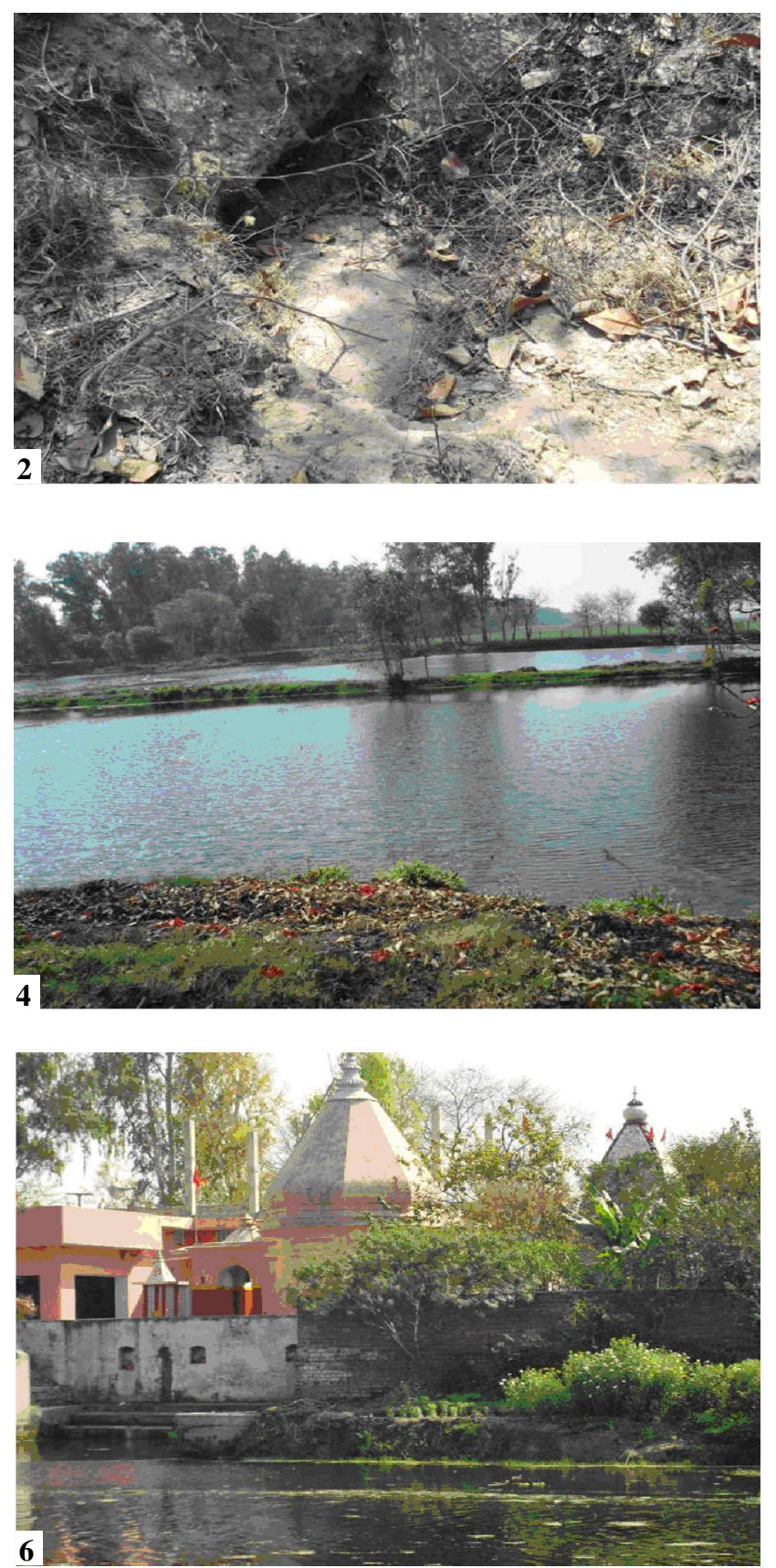

Figs. 1-2. Typical enterance of a tunnels ; Fig. 3. Water borne mugger ; Fig. 5. Ground borne mugger, Figs. 4 and 6: Typical premises of the Bhor-Sainda crocodile Sanctury in K urushetra district in $H$ aryana.

have reported the construction mannerism and composition of nests for breeding. However, in case of Indian Marsh Mugger, it has been observed in the present studies that no nests are constructed. Instead the clutch is laid inside the tunnels. Chowdhury and Whitaker (1979) have mentioned about egg collection in Tamil Nadu but have not mentioned about the practice of laying eggs inside tunnels by Marsh Mugger. In the present studies it has been observed that Indian Marsh Mugger lays eggs inside tunnels. Perhaps it is due to the absence of congenial atmosphere in the sanctuary in Haryana.

In so far as the seasonal tunnels residency is concerned, it is borne out that during extreme winter in December and January, muggers enter into tunnels early and depart in delayed fashion. On the other hand, during summer season, the Mugger delays their entry in evening and prepone departure in the dawn time.

As such, it seems, the stay in tunnels is guided by diurnal photo-periodicity in consonance with temperature regimes. However, in the last ten years (2000-10) the ambient and structural features have been 'dented' out of ignorance of the illiterate Govt. staffs members. Disturbance caused due to measures recommended and executed at the behest of wildlife Department officials 
have done immense harm to the tunnels. Repeated surveys reveal that the mouth of the tunnels is stuffed with sliding sand made loose by the interference of Govt. staff by way of remedying the locations. Continued disturbance due to the treading of the mound by the staff in the name of surveillance deters crocodiles to arrive in tunnels.

This has directly interfered with the breeding exercise also. It is recommended that the mound in the Sanctuary should not be structurally moulded in the name of establishing order. The tunnels should be left undisturbed.

\section{Conclusion}

Bhor Sainda crocodile sanctuary in Kurukshetra district in Haryana is an ideal site for discovering behavioural patterns of Indian marsh mugger. The Wildlife Department of Govt. of Haryana should not artificially moderate the physical features of the Sanctuary.

\section{ACKNOWLEDGEMENTS}

The author is grateful to Dr J. S. Yadav who so kindly brought a Camera and a tele-lens from Russia in 1986. This Camera has been the only precious tool in recording the observations.

\section{REFERENCES}

Bustard, H.R. and Singh, L.A.K. (1978). Studies on the Indian gharial, G avialis gangeticus (Gmelin) (Reptilia, Crocodilia). Change in terrestrial locomotory pattern with age. J. Bombay Nat. Hist. Soc., 74: 534-536

Chowdhury, B.C. and Whitaker, R. (1979). Crocodile egg collection in Tamil Nadu, Indian F orester, 105(2):121-128.

Gupta, R. C. and P.S. Hari (1990). On the burrow utilization by the Indian Marsh Crocodile, (Crocodylus palustris) Lesson (Reptilia: Crocodilidae) at Bhor Saidan Crocodile Sanctuary, Haryana. J . Environ. Biol.,11 (2):109-178.

Gupta, R. C. and Srihari, P. (1989). On the basking behaviour of the mugger, Crocodylus palustris Lesson (Reptilia Crocodilia) at Bhorsainda Crocodile Sanctuary, Haryana
State. J. Bombay nat. Hist. Soc., 86 (3): 170-174.

Gupta, R.C. and C. S. Bhardwaj. (1992). A Studies on the natural history of Indian Marsh Mugger (Crocodylus palntris) at Bhor Saidan Crocodile Sanctuary. J eevanti, 10: 19-25.

Gupta, R.C. and C.S. Bhardwaj. (1993a). Certain investigations into the daily life schedule of Indian Mugger (Crocodylus Palustris) lesson. J. Natcon., 5(1): 105-112.

Gupta, R.C. and C.S. Bhardwaj. (1993b). On the winter behavior of Indian Mugger, Cr ocodylus Palustris Lesson. Geobios N ews Reports, 12: 145-151.

Gupta, R.C. and C.S. Bhardwaj. (1993c). Burrow residency in case of Crocodylus palustris: Lesson at Bhor Saidan Crocodile Sanctuary in District Kurukshetra, Haryana. Zoo's Print Sept.: 13-14.

Josep, A., Chowhan, E, Khanna, K. and Whitaker, R. (1975). Marsh Crocodile, Crocodylus palustris in the Gir. J . B ombay Nat. Hist. Sco., 72(3): 211-219.

Kay, W.R. (2004a). Movements and home ranges of radiotracked Crocodylus por osus in the Cambridge Gulf region of Western Australia. Wildl. Res., 31:495-508.

Kay, W.R. (2004b). A new method for attaching electronic devices to crocodilians. Her petol. Rev., 35:4354-357.

Maskey, B.G.H. and Bellairs, A.D.A (1977). The narial excresence and pterygoid bulla of the gharial, Gavialis gangeticus (Crocodilia). J . Zool., L ond., 182: 541-558.

Rao, R.J. and Singh, L.A.K. (1994). Status and conservation of the gharial in India. In: Crocodiles. Proceedings of the 12th Working M eeting of the C rocodile Specialist G roup. IUCN, Gland, Switzerland. Vol.1. pp. 84-97.

Read, M.A., Grigg, G.C., Irwin, S.R., Shanahan,D. and Franklin, C. E. (2007). Determining the movement's patterns of adult estuarine crocodiles using satellite telemetry. Unpublished report.11.pp.Queensland Government parks and wildlife Service.Brisbane.

Singh, L.A.K. and Bustard, H.R. (1977). Studies on the Indian gharial, Gavialis gangeticus (Gmelin): V. Preliminary observations on maternal behavior. Indian Forester, 103: 671-678.

Whitaker, R. and Basu, D. (1983). The gharial (G avialis gangeticus): a review. J. Bombay $\mathrm{N}$ at. Hist. Soc. , 79: 531-548. 